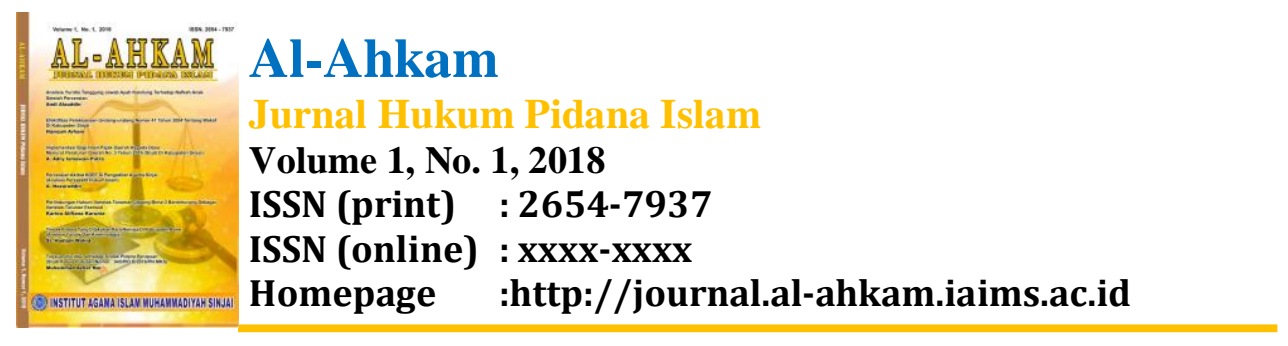

\title{
TINJAUAN YURIDIS TERHADAP TINDAK PIDANA PENIPUAN (Studi Kasus Putusan Nomor : 945/Pid.B/2016/ PN.Mks)
}

\author{
Muhammad Azhar Nur \\ IAI Muhammadiyah Sinjai, Jl. Sultan Hasanuddin No. 20, Sinjai
}

\begin{abstract}
Abstrak
Penelitian ini bertujuan untuk mengetahui penerapan hukum pidana terhadap tindak pidana penipuan dalam perkara putusan nomor 945/Pid.B/2016/PN.Mks dan untuk mengetahui pertimbangan hukum hakim dalam menjatuhkan putusan perkara nomor 945/Pid.B/2016/PN.Mks. Penelitian ini dilaksanakan di Kota Makassar, Propinsi Sulawesi Selatan, tepatnya dilakukan di Pengadilan Negeri Makassar. Penelitian ini dilakukan dengan cara pengambilan data yaitu dengan mengambil salinan dari salah satu putusan mengenai masalah tindak pidana penipuan dan wawancara dengan pihak yang bersangkutan yaitu dengan hakim yang menangani perkara penipuan dalam kasus ini. Selain itu, penulis juga melakukan studi kepustakaan dengan cara menelaah buku-buku, literatureliteratur dan peraturan perundang- undangan yang berkaitan dengan masalahmasalah yang akan dibahas dalam penulisan ini. Hasil penelitian menunjukkan bahwa, penerapan hukum pidana terhadap pelaku tindak pidana penipuan dalam putusan Nomor: 945/Pid.B/2016/PN.Mks, terdakwa didakwa menggunakan dakwaan alternatif yaitu kesatu Pasal 378 KUHP dan/atau kedua Pasal 372 KUHP. Dalam tuntutannya, Penuntut Umum menuntut terdakwa bersalah melakukan tindak pidana penipuan Pasal 378 KUHP, berdasarkan fakta-fakta hukum baik keterangan para saksi maupun terdakwa, dan barang bukti.Sehingga, penerapan hukum pidana pada perkara ini yaitu Pasal 378 KUHP telah sesuai dan tepat. Selanjutnya pertimbangan hukum Hakim dalam menjatuhkan sanksi pidana terhadap terdakwa dalam putusan Nomor: 945/Pid.B/2016/PN.Mks terdakwa dipidana dengan pidana penjara 1 (satu) tahun dan 6 (enam) bulan karena terbukti bersalah melakukan tindak pidana penipuan pada Pasal 378 KUHP. Pertimbangan Hakim dalam perkara ini telah sesuai dimana hakim telah mempertimbangkan baik dari fakta-fakta di persidangan, keterangan saksi maupun terdakwa, alat bukti yang ada, keyakinan hakim serta hal-hal yang mendukung.Namun, sanksi pidana yang dijatuhkan masih sangat ringan, serta tidak menimbulkan efek jera kepada terdakwa yang memberikan rasa takut dan trauma bagi terpidana pada khususnya, dan khalayak ramai pada umumnya, sebagaimana fungsi hukuman pidana pada mestinya.
\end{abstract}

Keywords: Penerapan, Hukum, Pidana, Penipuan, Putusan hakim. 


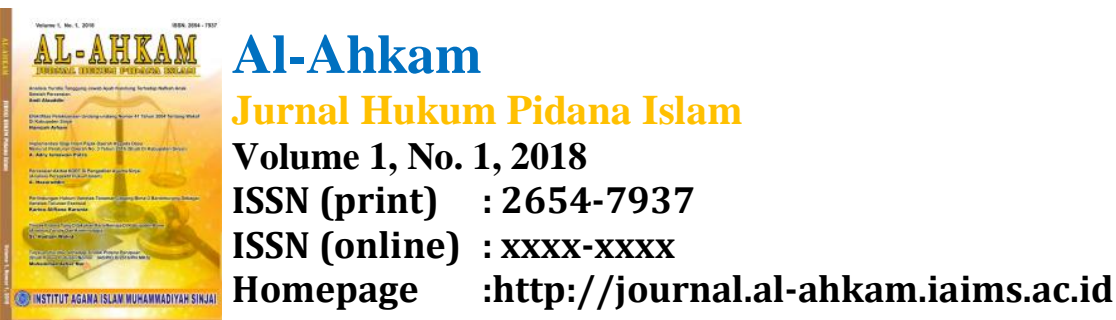


Volume 1, No. 1, 2018

ISSN (print) : 2654-7937

ISSN (online) : $x x x x-x \times x x$

Homepage :http://journal.al-ahkam.iaims.ac.id

\section{Pendahuluan}

Hukum pidana adalah bagian dari keseluruhan hukum yang berlaku di suatu negara, yang mengadakan dasar-dasar dan aturan-aturan untuk:

1. Menentukan perbuatan-perbuatan yang mana yang tidak boleh dilakukan, dilarang, dengan disertai ancaman atau sanksi yang berupa pidana tertentu bagi barangsiapa melanggar larangan tersebut.

2. Menentukan kapan dan dalam hal-hal apa kepada mereka yang telah melanggar laranganlarangan itu dapat dikenakan atau dijatuhi pidana sebagaimana yang telah diancamankan.

3. Menentukan dengan cara bagaimana pengenaan pidana itu dapat dilaksanakan apabila ada orang yang disangka telah melanggar larangan tersebut.

Secara ringkas, pengertian hukum pidana adalah hukum yang mengatur tentang pelanggaran dan kejahatan terhadap kepentingan umum.Pelanggaran dan kejahatan tersebut diancam dengan hukuman yang merupakan penderitaan atau siksaan bagi yang bersangkutan.Pelanggaran adalah perbuatan pidana yang ringan, ancaman hukumannya berupa denda atau kurungan.Sedangkan kejahatan adalah perbuatan pidana yang berat, ancaman hukumannya dapat berupa denda, hukuman penjara, hukuman mati, dan kadang kala masih ditambah dengan hukuman penyitaan barang-barang tertentu, pencabutan hak tertentu, serta pengumuman keputusan hakim.

Pada dasarnya, kehadiran hukum pidana di tengah masyarakat dimaksudkan untuk memberikan rasa aman kepada individu maupun kelompok dalam masyarakat dalam melaksanakan aktivitas kesehariannya. Rasa aman yang dimaksudkan dalam hal ini adalah perasaan tenang, tanpa ada kekhawatiran akan ancaman ataupun perbuatan yang dapat merugikan antar individu dalam masyarakat.Dalam kehidupan sehari-hari manusia sering dihadapkan kepada suatu kebutuhan yang mendesak, kebutuhan pemuas diri, dan bahkan kadang-kadang karena keinginan atau desakan untuk mempertahankan status diri. Masyarakat dewasa ini sering dihadapkan dengan masalah dari berbagai aspek, utamanya aspek ekonomi, dimana pada dasarnya seseorang akan selalu berusaha dalam memenuhi kebutuhan ekonominya dengan berbagai macam aktivitas penunjang ekonomi. Tak jarang, pemenuhan kebutuhan 
Volume 1, No. 1, 2018

ISSN (print) : 2654-7937

ISSN (online) : $x x x x-x x x x$

Homepage :http://journal.al-ahkam.iaims.ac.id

ekonomi berimbas hingga merugikan orang lain. Faktor lain yang menghambat pemenuhan kebutuhan ekonomi adalah minimnya lapangan pekerjaan membuat masyarakat sulit untuk mendapatkan penghasilan yang tetap dalam usaha memenuhi kebutuhan ekonominya. Karena dorongan berbagai macam kesulitan dalam pemenuhan kebutuhan ekonomi itulah permasalahan sering muncul hingga mengakibatkan sering terjadinya tindak pidana guna memenuhi kebutuhan ekonomi yang mendesak.

Di era globalisasi ini, jumlah pengangguran meningkat secara signifikan sehingga memberi pengaruh besar terhadap tingkat kesejahteraan masyarakat. Rendahnya tingkat kesejahteraan, minimnya tingkat pendidikan, serta kebutuhan ekonomi yang mendesak membuat masyarakat memilih cara-cara praktis dan taktis dalam memenuhi kebutuhannya tanpa peduli lagi terhadap norma atau kaidah hukum yang berlaku sehingga masyarakat tidak hanya mengalami krisis ekonomi, tetapi juga mengalami krisis moral yang berdampak pada terjadinya berbagai macam kejahatan dengan berbagai motif. Tidak bisa dipungkiri kejahatan semakin hari semakin merajalela di masyarakat.Tingkat kejahatan yang semakin tinggi sangat mengganggu keamanan dan ketertiban sehingga diperlukan adanya tindakan tegas untuk menindak pelaku kejahatan tersebut. Kejahatan atau perbuatan melanggar hukum tersebut salah satunya adalah tindak pidana penipuan yang merupakan tindak pidana terhadap harta benda yang diatur dalam Buku II KUHP ( tentang kejahatan) dalam Bab XXV, dimana kejahatan penipuan di dalam bentuknya yang pokok diatur di dalam Pasal 378 KUHP yang dirumuskan sebagai berikut :

"Barang siapa dengan maksud untuk menguntungkan diri sendiri atau orang lain secara melawan hukum, dengan memakai nama hukum palsu atau martabat palsu, dengan tipu muslihat, atau rangkaian kebohongan, menggerakkan orang lain untuk menyerahkan barang sesuatu kepadanya, atau supaya memberi utang maupun menghapuskan piutang, diancam karena penipuan dengan pidana penjara paling lama empat tahun."

Pada kejahatan penipuan dapat dijumpai kedua belah pihak yakni pihak yang tertipu dan pihak yang menipu.Dalam prakteknya sering kali dijumpai kasus penipuan yang terletak di perbatasan pidana dan perdata. Banyak transaksi dalam perdagangan yang dirasakan sangat merugikan suatu pihak dan yang tidak jarang dipaksakan penyelesaiannya melalui proses pidana, 
karena pihak yang merasa dirugikan merasa jika melalui proses perdata akan mengalami suatu keterlambatan yang dipandang sebagai tambahan kerugian bila diperhitungkan. Maka pihak yang merasa dirugikan tersebut lebih memilih proses pidana agar perkara dapat diadili seadil-adilnya. Tindak pidana penipuan tidak dapat dikatakan sebagai tindak pidana jika tidak memenuhi unsurunsur pokok tindak pidana penipuan yaitu:

1) Dengan maksud menguntungkan diri sendiri atau orang lain;

2) Secara melawan hukum;

3) Dengan memakai nama palsu atau martabat palsu, dengan tipu muslihat, ataupun dengan rangkaian perkataan bohong;

4) Menggerakkan orang lain;

5) Untuk menyerahkan suatu barang kepadanya atau untuk memberi utang ataupun menghapuskan piutang.

Dalam tindak pidana penipuan, terdapat banyak macam dan modus yang dilakukan pelaku untuk menggaet korban, salah satunya dengan menggunakan modus perdukunan.Kasus penipuan dengan modus perdukunan umumnya terjadi karena kurangnya wawasan dan pendidikan yang masyarakat miliki serta kepercayaan masyarakat terhadap dukun yang dianggap memiliki kekuatan gaib yang dapat membantu mereka melewati atau melalui kesulitan-kesulitan yang mereka alami. Karena alasan tersebut mereka kemudian terlena akan hal-hal yang berbau magis atau mistis untuk mendapatkan hasil yang lebih cepat dan praktis dibanding harus bersusah payah terlebih dahulu. Padahal tidak semua dukun atau paranormal dapat membantu kesulitan-kesulitan itu, bahkan beberapa atau sebagian dari mereka hanya berpura-pura membantu tapi nyata tidak melakukan apa-apa.Akibatnya banyak orang yang tertipu dan bukan menghilangkan kesulitan atau masalah yang mereka dapat, tetapi malah menambah kesulitan dan masalah mereka yaitu kerugian baik materiil ataupun immateriil yang dialami oleh korban.Modus perdukunan seperti dalam putusan nomor 945/Pid.B/2016/PN. MKS hanya didakwa dengan pasal 378 KUHP karena di dalam peraturan perundang-undangan yang lain belum diaturnya. Pengaturan tersebut dijadikan sebagai pertimbangan bagi hakim dalam menjatuhkan putusan terhadap pelaku tindak pidana penipuan.Hal tersebut dikarenakan tindak 
pidana penipuan dengan modus perdukunan dianggap oleh pembentuk undang-undang belum merupakan tindak pidana yang membahayakan kepentingan negara dan negara belum merasa harus membentuk undang undang yang mengatur tentang tindak pidana penipuan dengan modus perdukunan.Padahal kenyataannya sudah banyak kasus penipuan dengan modus perdukunan yang terjadi dan cukup meresahkan masyarakat. Berdasarkan hal diatas, maka penulis tertarik untuk mengkaji lebih jauh mengenai penerapan hukum pidana terhadap tindak pidana penipuan melalui judul: "Tinjauan Yuridis Terhadap Tindak Pidana Penipuan (Studi Kasus Putusan Nomor 945/Pid.B/2016/PN.MKS)"

\section{METODE PENELITIAN}

Lokasi penelitian yang dipilih Penulis untuk mendapatkan data dan informasi mengenai permasalahan dan pembahasan penulisan ini adalah bertempat di Kota Makassar, Propinsi Sulawesi Selatan. Lokasi tersebut menjadi pilihan Penulis sebab Kota Makassar merupakan wilayah hukum Pengadilan Negeri Makassar yang telah mengadili tindak pidana penipuan dengan Nomor: 945/Pid.B/2016/PN.Mks. Pengumpulan data dan informasi dilaksanakan di berbagai tempat yang dianggap Penulis dapat memberikan kontribusi dalam penelitian ini. Tempat yang dimaksud adalah Pengadilan Negeri Makassar.Jenis penelitian dalam Penulisan hukum ini adalah penelitian hukum normatif yang didukung dengan penelitian lapangan.Penelitian hukum normatif adalah penelitian yang mengkaji norma-norma yang berlaku

meliputi Undang-Undang yang mempunyai relevansi dengan permasalahan sebagai bahan hukum sumbernya.Penelitian hukum ini juga memerlukan data yang berupa tulisan dari para ahli atau pihak yang berwenang serta sumber-sumber lain yang memiliki relevansi dengan permasalahan yang diteliti.

\section{PEMBAHASAN}

\section{Definisi Tindak Pidana}

Para pakar asing Hukum Pidana menggunakan istilah tindak pidana dengan istilah:

1. Strafbaar Feit adalah peristiwa pidana; 
Volume 1, No. 1, 2018

ISSN (print) : 2654-7937

ISSN (online) : $x x x x-x x x x$

Homepage :http://journal.al-ahkam.iaims.ac.id

2. Strafbare Handlung diterjemahkan dengan Perbuatan Pidana, yang digunakan oleh para sarjana Hukum Pidana Jerman; dan

3. Criminal Act diterjemahkan dengan istilah Perbuatan Kriminal.

Tindak pidana yang dalam bahasa Belanda Strafbaarfeit disebut terdiri atas tiga kata, yaitu straf, baar, dan feit. Yang masing-masing memiliki arti:

1) Straf diartikan sebagai pidana dan hukum,

2) Baar diartikan sebagai dapat dan boleh,

3) Feit diartikan sebagai tindak, peristiwa, pelanggaran, dan perbuatan.

Jadi, istilah strafbaarfeit adalah peristiwa yang dapat dipidana atau perbuatan yang dapat dipidana. Dalam bukunya, Adami Chazawi menjelaskan bahwa ada tujuh istilah strafbaar feit yang di kenal di Indonesia. Istilah-istilah yang pernah digunakan, baik dalam perundangundangan yang ada maupun dalam berbagai literatur hukum sebagai terjemahan dari istilah strafbaar feit antara lain yaitu tindak pidana, peristiwa pidana, delik, pelanggaran pidana, perbuatan yang boleh di hukum, perbuatan yang dapat dihukum, dan perbuatan pidana.

H.R Abdussalam merumuskan bahwa:

"Kejahatan atau tindak pidana adalah perbuatan melakukan atau tidak melakukan sesuatu yang oleh peraturan perundang-undangan dinyatakan sebagai perbuatan yang dilarang dan diancam dengan pidana.Untuk dapat dipidananya perbuatan yang dilarang dan diancam pidana oleh peraturan perundang-undangan, perbuatan tersebut harus juga bersifat melawan hukum atau bertentangan dengan kesadaran hukum masyarakat."

Simons mengemukakan bahwa straffbaar feit adalah suatu tindakan melanggar hukum yang dengan sengaja telah dilakukan oleh seseorang yang dapat dipertanggung jawabkan atas tindakannya, yang dinyatakan sebagai dapat dihukum.

Van Manel merumuskan strafbaar feit adalah:

"kelakuan orang (menselijke gedraging) yang di rumuskan dalam wet, yang bersifat melawan hukum, yang oatut dipidana (strafwaardig) dan dilakukan dengan kesalahan."

Menurut Pompe, perkataan "tindak pidana" secara teoretis dapatdirumuskan sebagai berikut : 
"Suatu pelanggaran norma atau gangguan terhadap tertib hukum yang dengan sengaja ataupun tidak dengan sengaja telah dilakukan oleh seorang pelaku yang penjatuhan hukuman terhadap pelaku tersebut adalah perlu demi terpeliharanya tertib hukum dan terjaminnya kepentingan umum."13

Menurut kamus hukum, tindak pidana adalah:

"suatu perbuatan pidana yang dapat dijatuhi hukuman; setiap perbuatan yang diancam hukuman sebagai kejahatan atau pelanggaran baik yang disebut dalam KUHP maupun peraturan perundang-undangan lainnya."

Moeljatno menyebutkan bahwa tindak (perbuatan) pidana adalah perbuatan yang dilarang oleh undang-undang dan diancam dengan pidana, barang siapa yang melanggarnya.Pengertian ini merujuk kepada sifat dilarangnya perbuatan tertentu dengan ancaman pidana tertentu jika dilanggar.Dalam konteks ini, perbuatan merupakan unsur pembentuk tindak pidana, karena keberadaan pelaku tindak pidana, ancaman pidana, sifat melawan hukum, dan alasan pembenar berpusat kepada perbuatan. Dengan kata lain, hal-hal tersebut bertujuan untuk mempertegas dilarangnya perbuatan tertentu.

Dari banyaknya istilah tentang strafbaarfeit, penulis berpendapat menggunakan istilah tindak pidana dengan alasan bahwa istilah tindak pidana bukan lagi menjadi istilah awam bagi masyarakat Indonesia dan telah digunakan dalam berbagai peraturan perundang-undangan kita, misalnya Undang-Undang Tindak Pidana Suap, Undang-Undang Tindak Pidana Korupsi, Undang-Undang Tindak Pidana Imigrasi, Undang-Undang Tindak Pidana Pencucian Uang dan RUU KUHP Tahun 2007 serta pada praktik penegakan hukum yakni putusan pada Pengadilan Negeri, Mahkamah Agung, dan sebagainya. Perbedaan definisi diatas tidak menjadi masalah asalkan diketahui maksudnya dan dalam hal ini yang terpenting adalah isi dari pengertian tindak pidana dari rumusan yang ditetapkan oleh Tim Pengkajian Hukum Pidana Nasional sebagai berikut:

"Tindak pidana ialah perbuatan melakukan atau tidak melakukan sesuatu yang oleh peraturan perundang-undangan dinyatakan sebagai perbuatan yang dilarang dan diancam dengan pidana."

\section{Pengetian Tindak Pidana Penipuan}


Tindak pidana penipuan dalam hukum pidana merupakan kejahatan terhadap harta benda yang diatur dalam Buku II KUHP dalam Bab XXV dari pasal 378 sampai dengan pasal 395. Setiap pasal tersebut mempunyai bentuk-bentuk penipuan yang berbeda-beda, begitu pula pengertian dari tindak pidana itu sendiri berbeda tetapi memiliki makna yang sama. Mengenai pengertian dari penipuan, Penulis akan menguraikan sebagai berikut:

1) Penipuan menurut pengertian Bahasa Menurut Kamus Besar Bahasa Indonesia (KBBI) penipuan berasal dari kata tipu yang berarti adalah perbuatan atau perkataan yang tidak jujur atau bohong, palsu, dan sebagainya dengan maksud untuk menyesatkan, mengakali atau mencari untung. Sedangkan penipuan adalah proses, cara, perbuatan menipu serta perkara menipu.

2) Penipuan menurut pengertian KUHP Pengertian tindak pidana penipuan diatur dalam Buku II KUHP dalam Bab XXV dari pasal 378 sampai dengan pasal 395.Setiap pasal tersebut mempunyai bentuk-bentuk penipuan yang berbeda-beda.Rumusan penipuan dalam KUHP bukanlah suatu definisi melainkan hanyalah untuk menetapkan unsur-unsur suatu perbuatan sehingga dapat dikatakan sebagai penipuan dan pelakunya dapat dipidana. Penulis akan menguraikan sebagai berikut, Pasal 378 KUHP:

"Barangsiapa dengan maksud menguntungkan diri sendiri atau diri orang lain dengan melawan hukum, baik dengan memakai nama palsu atau keadaan palsu, maupun dengan tipu daya, ataupun dengan rangkaian perkataan-perkataan bohong, membujuk orang supaya menyerahkan barang, atau supaya membuat utang atau menghapuskan piutang”.

Berdasarkan unsur-unsur dari tindak pidana penipuan yang terkandung dalam rumusan Pasal 378 KUHP di atas. Maka R. Sugandhi mengemukakan pengertian penipuan bahwa:

"Penipuan adalah tindakan seseorang dengan tipu muslihat, rangkaian kebohongan, nama palsu dan keadaan palsu dengan maksud menguntungkan diri sendiri dengan tiada hak.Rangkaian kebohongan ialah susunan kalimat-kalimat bohong yang tersusun demikian rupa yang merupaka cerita sesuatu yang seakan-akan benar".

Penipuan adalah suatu bentuk dari berkicau. Sifat umum dari perbuatan berkicau itu adalah bahwa orang dibuat keliru, dan oleh karena itu ia rela menyerahkan barangnya atau uangnya. Pidana bagi tindak pidana penipuan ialah pidana penjara maksimum empat tahun tanpa 
Volume 1, No. 1, 2018

ISSN (print) : 2654-7937

ISSN (online) : $x x x x-x x x x$

Homepage :http://journal.al-ahkam.iaims.ac.id

alternative denda.Jadi tindak pidana penipuan dipandang lebih berat daripada tindak pidana penggelapan karena pada tindak pidana penggelapan ada alternatif denda.Oleh karena itu, penuntut umum yang menyusun dakwaan primair dan subsidair kedua pasal ini harus mencantumkan tindak pidana penipuan pada dakwaan primair, sedangkan dakwaan subsidiair ialah penggelapan.

\section{Tinjauan Umum Tentang Putusan Hakim}

Menjadi hakim merupakan profesi yang cukup berat dan sulit karena dapat hakim yang menentukan apakah seseorang itu nantinya dapat memperoleh kebebasan ataukah hukuman.Jika terjadi hakim melakukan kesalahan dalam mengambil atau menjatuhkan keputusan maka hal itu dapat merenggut keadilan, nyawa, kemerdekaan, harta benda, kehormatan serta martabat yang dimiliki masyarakat dan setiap insan.Hakim yang bebas dan tidak memihak telah menjadi ketentuan universal.Ia menjadi ciri pula suatu negara hukum. The Universal Declaration of Human Rights, pada Pasal 10 mengatakan sebagai berikut:

"Everyone is entitled in full equality to a fair and public hearing by an independent and impartial tribunal in the determination of his rights and obligation and of any criminal charge against him." (Setiap orang berhak dalam persamaan sepenuhnya didengarkan suaranya dimuka umum dan secara adil oleh pengadilan yang merdeka dan tak memihak, dalam hal menetapkan hak-hak dan kewajiban-kewajibannya dan dalam setiap tuntutan pidana yang ditujukan padanya).

Pengertian putusan pengadilan terdapat dalam Pasal 1 angka 11 KUHAP yaitu pernyataan hakim yang diucapkan dalam sidang pengadilan terbuka, yang dapat berupa pemidanaan atau bebas atau lepas dari segala tuntutan hukum dalam hal menurut cara yang diatur dalam undang-undang. Pengertian "Putusan Pengadilan" menurut Leden Marpaung adalah:

"Putusan adalah hasil atau kesimpulan dari sesuatu yang telah dipertimbangkan dan dinilai dengan semasak-masaknya yang dapat berbentuk tertulis maupun lisan."

Setelah pemeriksaan perkara dinyatakan selesai oleh hakim, maka sampailah hakim pada tugasnya, yaitu menjatuhkan putusan, yang akan memberikan penyelesaian pada suatu perkara yang terjadi antara negara dengan warga negaranya. Putusan yang demikian biasanya disebut sebagai putusan akhir. 
Menurut ketentuan pasal 193 KUHAP ada beberapa jenis putusan akhir yang dapat dijatuhkan oleh hakim dalam suatu perkara, yaitu sebagai berikut:

a) Putusan Bebas (Vrijspraak) Putusan bebas (Vrijspraak) adalah putusan yang dijatuhkan oleh hakim yang berupa pembebasan terdakwa dari suatu tindak pidana yang dituduhkan terhadapnya, apabila dalam dakwaan yang diajukan oleh penuntut umum terhadap terdakwa di persidangan, ternyata setelah melalui proses pemeriksaan dalam persidangan, tidak ditemukannya adanya bukti-bukti yang cukup yang menyatakan bahwa terdakwalah yang melakukan tindak pidana dimaksud, maka kepada terdakwa haruslah dinyatakan secara sah dan meyakinkan tidak terbukti secara sah dan meyakinkan besalah melakukan tindak pidana sebagaiman dalam dakwaan penuntut umum, sehingga oleh karena itu terhadap terdakwa haruslah dinyatakan dibebaskan dari segala dakwaan (Pasal 191 ayat (1) KUHAP). b) Putusan Pelepasan dari Segala Tuntutan Hukum ( Onslaag van Alle Recht Vervolging) Putusan pelepasan terdakwa dari segala tuntutan hukum dijatuhkan oleh hakim apabila dalam persidangan ternyata terdakwa terbukti secara sah dan meyakinkan bersalah sebagaimana dalam dakwaan Penuntut Umum, tetapi diketahui bahwa perbuatan tersebut bukan merupakan perbuatan pidana, dan oleh karena itu terhadap terdakwa akan dinyatakan lepas dari segala tuntutan hukum (Pasal 191 ayat (2) KUHAP). c) Putusan Pemidanaan Suatu putusan pemidanaan di jatuhkan di rumuskan pada pasal 193 ayat (1) KUHAP yaitu jika pengadilan berpendapat bahwa terdakwa bersalah melakukan tindak pidana yang didakwakan kepadanya, maka pengadilan menjatuhkan pidana. Dapat dibandingkan dengan perumusan Van Bemmelen sebagai berikut:

"Een veroordeling zal de rechter uitspreken, als hij de overtuiging heeft verkregen, dat de verdachte het the laste gelegde feit heeft begaan en hij feit en verdachte ook strafbaar acht" (putusan pemidanaan dijatuhkan oleh hakim jika ia telah mendapat keyakinan bahwa terdakwa telah melakukan perbuatan yang didakwakan dan ia menganggap bahwa perbuatan dan terdakwa dapat dipidana). Putusan hakim dapat dieksekusi bila putusan tersebut telah mempunyai kekuatan hukum tetap, yang telah diterima oleh para pihak yang bersangkutan.Putusan yang berupa pemidanaan berupa pidana seperti yang diatur dalam Pasal 10 KUHP.

\section{Penerapan Hukum Pidana terhadap Tindak Pidana Penipuan}


Penerapan hukum adalah suatu peraturan atau perundang-undangan yang telah disahkan selanjutnya diundangkan dilembaran negara, posisi ini undang-undang atau peraturan tersebut telah diterapkan.Hakim dalam menjatuhkan putusannya kepada terdakwa berdasarkan tingkat kesalahan yang telah di lakukan oleh terdakwa dengan melihat latar belakang dari tindak pidana tersebut dimana sanksi pidana yang di jatuhkan telah sesuai dengan berdasarkan fakta-fakta hukum yang terungkap dipersidangan, keterangan saksi-saksi maupun keterangan terdakwa dan juga barang bukti yang ada.

Berdasarkan putusan perkara nomor 945/Pid.B/2016/PN.Mks tentang kasus tindak pidana penipuan. Tindak pidana penipuan ini terjadi diperkirakan pada bulan Desember Tahun 2014 atau setidak-tidaknya dalam kurun waktu Tahun 2014 bertempat di rumah kontrakan Terdakwa di Jl. Towoti Kec. Tamalate kota Makassar, atau setidak-tidaknya disuatu tempat lain yang masih termasuk dalam wilayah Hukum Pengadilan Negeri Makassar dimana Terdakwa dalam kasus ini bernama SITTI NURBAYA. Tindak pidana penipuan ini berawal ketika Terdakwa bertemu dengan saksi RIOLA dan mengatakan bahwa saksi RIOLA telah diguna-gunai oleh orang dan jika tidak segera diobati saksi RIOLA akan meninggal. Mendengar penyataan Terdakwa, saksi RIOLA tanpa berpikir panjang mempercayai perkataan Terdakwa.Kemudian Terdakwa mengatakan pada saksi RIOLA bahwa terdakwa bisa mengobatinya. Dan sebagai persyaratan pengobatan, Terdakwa meminta uang sebesar Rp. 35.000.000,00 (tiga puluh lima juta Rupiah), dan penyerahan uang dilakukan secara bertahap awalnya Rp.5.000.000,00 (lima juta Rupiah), kemudian yang kedua saksi RIOLA serahkan lagi pada terdakwa sebesar Rp. 15.000.000,00 (lima belas juta Rupiah) yang kemudian Terdakwa mengembalikan Rp. 10.000.000,00 (sepuluh juta Rupiah) selanjutnya saksi RIOLA menyerahkan uang sebesar Rp. 20.000.000,00 (dua puluh juta Rupiah) setelah itu sebesar Rp. 15.000.000,00 (lima belas juta Rupiah) Karena menurut Terdakwa uang senilai Rp. 35.000.000,00 (tiga puluh lima juta Rupiah) akan Terdakwa simpan dulu dirumahnya untuk dikawaru (disimpan di lemari) selama 7 (tujuh) Jum'at nanti perbulannya akan dikembalikannya pada saksi RIOLA sebesar Rp.1.000.000,00 (satu juta Rupiah) untuk digunakan belanja makanan agar penyakit yang ada dalam tubuh saksi RIOLA keluar. Uang tersebut saksi serahkan di jalan di Taman Toraja diatas mobil.Selanjutnya saksi menyerahkan 
uang kepada Terdakwa lagi sebesar Rp.5.600.000,00 (lima juta enam ratus ribu Rupiah) dimana Terdakwa menyampaikan bahwa untuk digunakan Karena ada kecolongan di kantornya. Sehingga total keseluruhan yang saksi serahkan pada Terdakwa sebesar Rp. 50.600.000,00 (lima puluh juta enam ratus ribu Rupiah) serta beberapa buah perhiasan emas milik saksi RIOLA yang menurut Terdakwa untuk disimpan di rumahnya dikawaru 7 (tujuh) Jum'at dan setelah 7 (tujuh) Jum'at berlalu saksi meminta kembali perhiasan miliknya, namun Terdakwa sampaikan bahwa perhiasan emas milik saksi ada di dalam lemarinya takut untuk mengembalikan pada saksi namun setelah saksi mendesak Terdakwa untuk menunjukkan perhiasan emas miliknya dan barulah Terdakwa mengaku kalua perhiasan emas milik saksi telah digadaikan dan uang milik saksi juga telah habis Terdakwa gunakan untuk keperluan pribadinya.

Berdasarkan uraikan kasus diatas, dapat ditarik kesimpulan bahwa penerapan hukum yang dijatuhkan pada terdakwa dengan melihat surat dakwaan dari jaksa penuntut umum merupakan dakwaan alternatif dimana dakwaan kesatu melanggar pasal 378 KUHP, sedangkan dakwaan kedua melanggar pasal 372 KUHP. Dan dalam tuntutannya, jaksa penuntut umum lebih menerapkan pasal 378 KUHP (tindak pidana penipuan) dibandingkan dengan pasal 372 KUHP (tindak pidana penggelapan).

Menurut analisa penulis, dakwaan jaksa penuntut umum yang tercantum dalam tuntutannya lebih menerapkan tindak pidana penipuan (pasal 378 KUHP) dibandingkan tindak pidana penggelapan (pasal 372 KUHP) karena dalam kasus yang penulis bahas ini terdakwa terbukti secara sah dan meyakinkan bersalah telah melakukan tindak pidana penipuan (pasal 378 KUHP) hal tersebut dapat di buktikan dari bahwa pada Pasal 378 KUHP telah mencocoki semua unsur-unsur dalam ketentuan Pasal tersebut dimana terdakwa dengan maksud menguntungkan diri sendiri atau orang lain secara melawan hukum, dengan memakai nama palsu atau martabat palsu, dengan tipu muslihat ataupun rangkaian perkataan bohong, menggerakkan orang lain supaya memberikan suatu barang atau supaya membuat utang atau menghapuskan piutang. Dengan demikian pada kasus ini penerapan Pasal 378 KUHP telah mencocoki unsur-unsur yang ada dan perbuatan terdakwa telah terbukti melakukan tindak pidana penipuan. Setelah penulis menganalisis dakwaan jaksa penuntut umum dalam kasus tersebut di atas, maka dakwaan jaksa penuntut 
Volume 1, No. 1, 2018

ISSN (print) : 2654-7937

ISSN (online) : $x \times x x-\times x x x$

Homepage :http://journal.al-ahkam.iaims.ac.id

umum telah memiliki sifat dan hakekat suatu dakwaan, yang telah menguraikan secara cermat, jelas dan lengkap baik mengenai identitas terdakwa maupun mengenai uraian dari perbuatan yangdilakukan oleh terdakwa dan disertai dengan waktu dan tanggal perbuatannya serta tempat perbuatan itu berlangsung, sehingga dengan demikian maka menurut hemat penulis dakwaan tersebut secara formil telah memenuhi persyaratan sesuai dengan Pasal 378 KUHP. Melihat penerapan hukum pidana materil yang dikaitkan pula dengan fakta-fakta yang terdapat pada keterangan saksi-saksi, keterangan ahli serta keterangan terdakwa yaitu SITTI NURBAYA, terdakwa dinyatakan telah melanggar Pasal 378 KUHP dengan oleh karena terpenuhinya unsurunsur yang terdapat dalam pasal tersebut yaitu:

1. Barang siapa.

2. Dengan maksud menguntungkan diri sendiri atau orang lain secara melawan hukum.

3. Dengan memakai nama palsu atau martabat palsu, dengan tipu muslihat, ataupun dengan rangkaian perkataan bohong.

4. Menggerakkan orang lain untuk menyerahkan sesuatu barang kepadanya, atau untuk memberi hutang ataupun menghapuskan piutang.

Berdasarkan uraian unsur-unsur diatas, maka jika dikaitkan dengan fakta-fakta hukum yang terungkap di persidangan, dapat dilihat bahwa perbuatan terdakwa telah memenuhi unsur-unsur yang terdapat pada pasal 378 KUHP, yaitu:

\section{Barangsiapa}

Yang dimaksud unsur barangsiapa disini adalah siapa saja atau setiap orang sebagai subjek hukum yang didakwa sebagai pelaku tindak pidana dan dapat mempertanggung jawabkan perbuatannya. Berdasarkan fakta yang terungkap dipersidangan yang diperoleh dari keterangan saksi-saksi serta keterangan terdakwa sendiri yang telah membenarkan identitasnya dalam surat dakwaan Jaksa Penuntut Umum, maka terdakwa yang diajukan dalam persidangan ini adalah SITTI NURBAYA sebagai manusia yang dapat mempertanggung jawabkan perbuatannya. Berdasarkan fakta tersebut diatas, maka unsur "barangsiapa" telah terpenuhi secara sah dan meyakinkan menurut hukum.

2. Dengan maksud menguntungkan diri sendiri atau orang lain secara melawan hukum 
Volume 1, No. 1, 2018

ISSN (print) : 2654-7937

ISSN (online) : $x \times x x-\times x x x$

Homepage :http://journal.al-ahkam.iaims.ac.id

Merujuk pada beberapa posisi kasus yang telah diuraikan di atas, jika dihubungkan dengan fakta hukum yang terungkap dalam persidangan berdasarkan alat bukti berupa keterangan para saksi yang telah disumpah maupun dari ketengan terdakwa sendiri, maka diperoleh fakta-fakta hukum sebagai berikut:

a) Unsur dengan maksud menguntungkan diri sendiri yaitu

Terdakwa membujuk saksi RIOLA HAYA NUR dan saksi RAHMATIA agar memberikan sejumlah uang dan perhiasan yang dilakukan secara bertahap dengan untuk disimpan dilemari dan dipakai ritual guna mendapat kesembuhan.Namun pada kenyataannya, Terdakwa telah menggadaikan emas dan menggunakan uang tersebut untuk keperluan pribadinya.

b) Unsur secara melawan hukum

Adalah terdakwa telah menikmati uang dari hasil kejahatannya yaitu dengan menggadaikan perhiasan emas dan uang yang tak lain milik Saksi Riola Haya Nur dan saksi Rahmatia secara pribadi dengan melakukan rangakian kebohongan atau tipu muslihat.

Berdasarkan fakta-fakta yang telah Penulis uraikan diatas, maka unsur "dengan maskud menguntungkan diri sendiri atau orang lain secara melawan hukum" telah terpenuhi dan terbukti secara sah dan meyakinkan menurut hukum.

3. Dengan memakai nama palsu atau martabat palsu, dengan tipu muslihat, ataupun dengan rangkaian perkataan bohong, menggerakkan orang lain untuk menyerahkan sesuatu barang kepadanya, atau untuk memberi hutang ataupun menghapuskan piutang.

Unsur dengan memakai nama palsu atau martabat palsu, dengan tipu muslihat, ataupun dengan rangkaian perkataan bohong, menggerakkan orang lain untuk menyerahkan sesuatu barang kepadanya, atau untuk memberi hutang ataupun menghapuskan piutang merupakan unsur yang terdiri dari beberapa sub unsur yang bersifat alternatif, artinya jika salah satu dari unsur tersebut terbukti, maka yang lainnya tidak perlu dibuktikan lagi karena dengan sendirinya secara menyeluruh unsur ini telah terbukti. Dari unsur dengan memakai tipu muslihat, ataupun dengan rangkaian perkataan bohong dapat ditemukan fakta-fakta yang di peroleh dari persidangan yaitu terdakwa membujuk dengan mengatakan kepada korban agar menyerahkan sejumlah uang dan perhiasan emas yang diberikan secara bertahap untuk disimpan di lemari dan dipakai ritual 
Volume 1, No. 1, 2018

ISSN (print) : 2654-7937

ISSN (online) : $x x x x-x x x x$

Homepage :http://journal.al-ahkam.iaims.ac.id

dengan dijanjikan kesembuhan, namun kenyataannya sejumlah uang dan perhiasan emas yang telah diberikan oleh korban justru terdakwa gunakan uang dan menggadaikan emas tersebut untuk keperluan pribadinya serta kesembuhan yang dijanjikan oleh terdakwa tidak berhasil. Unsur menggerakkan orang untuk menyerahkan sesuatu barang kepadanya dapat dibuktikan dengan melihat fakta-fakta yang telah terungkap dipersidangan yaitu Terdakwa yang mengaku dirinya paranormal (orang yang mendoakan) dengan menggerakkan saksi RIOLA HAYA NUR dan saksi RAHMATIA menyerahkan uang dan perhiasan emasnya kepada terdakwa untuk kepentingan ritual.

Berdasarkan fakta-fakta yang telah diuraikan diatas, maka unsur "dengan memakai nama palsu atau martabat palsu, dengan tipu muslihat, ataupun dengan rangkaian perkataan bohong, menggerakkan orang lain untuk menyerahkan sesuatu barang kepadanya, atau untuk memberi hutang ataupun menghapuskan piutang" telah terpenuhi dan terbukti secara sah dan meyakinkan menurut hukum. Berdasarkan pembahasan yang telah penulis jelaskan diatas, maka terdakwa dinyatakan telah terbukti secara sah dan meyakinkan bersalah melakukan tindak pidana penipuan sesuai Pasal 378 KUHP. Keputusan majelis hakim yang menyatakan bahwa terdakwa telah melanggar Pasal 378 KUHP menurut Penulis sudah tepat atau dengan kata lain pasal yang didakwakan oleh jaksa penuntut umum dan selanjutnya diterapkan oleh Majelis Hakim sudah tepat sebab perbuatan terdakwa telah dapat dibuktikan secara sah dan meyakinkan memenuhi rumusan tindak pidana yang didakwakan dalam Pasal 378 KUHP.

\section{Pertimbangan Hukum Hakim dalam Menjatuhkan Putusan Perkara Nomor 945/Pid.B/2016/PN.Mks}

Peranan seorang Hakim sebagi pihak yang menjatuhkan putusan pemidanaaan tidak mengabaikan hukum atau norma serta peraturan yang hidup dalam masyarakat sebagaimana yang diatur dalam Pasal 5 ayat (1) Undang-Undang Nomor 48 Tahun 2009 tentang Asas Penyelenggaraan Kekuasaan Kehakiman. Hakim mempunyai substansi untuk menjatuhkan pidana, akan tetapi dalam menjatuhkan pidana tersebut Hakim dibatasi oleh aturan-aturan pemidanaaan, masalah pemberian pidana ini bukanlah masalah yang mudah seperti perkiraan 
Volume 1, No. 1, 2018

ISSN (print) : 2654-7937

ISSN (online) : $x \times x x-\times x x x$

Homepage :http://journal.al-ahkam.iaims.ac.id

orang, karena Hakim mempunyai kebebasan untuk memutus atau menetapkan jenis pidana, cara pelaksanaan pidana, dan tinggi rendahnya pidana.

Putusan adalah hasil atau kesimpulan dari sesuatu yang telah dipertimbangkan dan dinilai dengan semasak-masaknya yang dapat berbentuk tertulis maupun lisan.Pada ketentuan pasal 193 KUHAP, ada beberapa jenis putusan akhir yang dapat dijatuhkan oleh hakim dalam suatu perkara, yaitu putusan bebas, putusan lepas, dan putusan pemidanaan.

Berdasarkan uraian amar putusan, hakim menjatuhkan putusan pemidanaan kepada Terdakwa SITTI NURBAYA dengan pidana penjara selama 1 (satu) tahun 6 (enam) bulan, karena terdakwa terbukti secara sah dan menyakinkan telah melakukan perbuatan tindak pidana penipuan sebagaimana yang diatur dalam pasal 378 KUHP. Hakim telah mengambil pertimbangan dalam menjatuhkan putusan terhadap terdakwa dengan didasari fakta-fakta yuridis yang terungkap didalam persidangan dan oleh undang-undang telah ditetapkan sebagai hal yang dimaksudkan tersebut diantaranya adalah dakwaan Jaksa Penuntut Umum, keterangan terdakwa dan saksi, barang-barang bukti dan unsur-unsur tindak pidana yang didakwakan, dan pertimbangan non yuridis yang terdiri dari latar belakang perbuatan terdakwa, kondisi terdakwa, serta kondisi ekonomi terdakwa, ditambah hakim haruslah meyakini apakah terdakwa melakukan perbuatan pidana atau tidak sebagaimana yang termuat dalam unsur-unsur tindak pidana yang didakwakan kepadanya yaitu Pasal 378 KUHP. Dalam kasus penipuan ini, profesi yang di gunakan oleh Terdakwa adalah seorang paranormal (orang yang mendoakan)atau lebih tepat disebut perdukunan. Seperti yang sudah penulis uraikan pada tinjauan pustaka tentang peraturanperaturan yang mengatur soal perdukunan, bahwa didalam KUHP tepatnya pada Pasal 545 dan Pasal 546 yang berbunyi:

a. Pasal 545

"Barangsiapa pencahariannya menjadi ahli nujum meramalkan atau menerangkan mimpi, dihukum kurungan enam hari atau denda sebanyak-banyaknya Rp. 375,- 4) Jika pada waktu melakukan pelanggaran itu belum lalu satu tahun sejak ketetapan putusan hukuman yang dahulu bagi sitersalah Karena pelanggaran yang serupa itu juga, maka hukuman itu dapat dilipat dua.

b. Pasal 546 
Dengan hukuman kurungan selama-lamanya tiga bulan atau denda sebanyak-banyak Rp. 4.500,: 1e. barangsiapa menjual, menawarkan, menyerahkan, membagikan atau menyediakan untuk dijual atau untuk dibagikan jimat, penangkal atau benda lain, dengan berdalih benda itu ada kesaktiannya; 2e. barangsiapa mengajarkan ilmu atau kepandaian, yang maksudnya menerbitkan kepercayaan, bahwa orang dapat melakukan perbuatan yang dapat dihukum, dengan tidak akan mendapat sesuatu bahaya.

Berkaitan dengan Pasal 545 dan Pasal 546 KUHP, wawancara yang dilakukan oleh penulis dengan salah satu hakim yang menangani kasus dengan nomor perkara 945/Pid.B/2016/PN.Mks yaitu IMAM SUPRIYADI, SH., MH., penulis menanyakan apa alasan atau pertimbangan hakim tidak menerapkan pasal 545 dan pasal 546 KUHP. Hakim menerangkan bahwa: "Dalam kasus ini, hakim tidak menerapkan pasal 545 dan Pasal 546 karena Terdakwa tidak terbukti merupakan seorang paranormal walaupun ia sudah di kenal sebagai seorang paranormal atau dukun sekitar tahun 2014. Pada saat para saksi memberikan keterangan didalam persidangan, Saksi mengatakan bahwa saksi merasa terhipnotis sehingga saksi dengan mudah percaya bahwa Terdakwa merupakan paranormal atau dukun yang dapat mengobati mereka.Lalu pada Pasal 546, hakim tidak menerapkannya karena di putusan memang menyebutkan bahwa Terdakwa memberikan air untuk kesembuhan selama 9 (sembilan) minggu, tetapi air itu bukan diperoleh dari hasil jualan Terdakwa.Jadi unsur-unsur dari Pasal 545 dan Pasal 546 didalam KUHP tidak terpenuhi."

Selanjutnya, pada perkara ini putusan yang dijatuhkan oleh Majelis Hakim lebih rendah dari tuntutan Jaksa Penuntut Umum, hal ini disebabkan karena adanya keadaan-keadaan yang memberatkan dan meringankan bagi terdakwa yang menjadi petimbangan Majelis Hakim dalam menjatuhkan putusan. Adapun keadaan-keadaan yang memberatkan dan meringankan terdakwa dalam perkara ini yaitu:

Keadaan-keadaan yang memberatkan:

1) Akibat perbuatan Terdakwa, saksi RIOLA HAYA NUR dan saksi RAHMATIA mengalami kerugian sekira Rp. 50.600.000,00 dan perhiasan emas seberat 31 (tiga puluh satu) gram; 


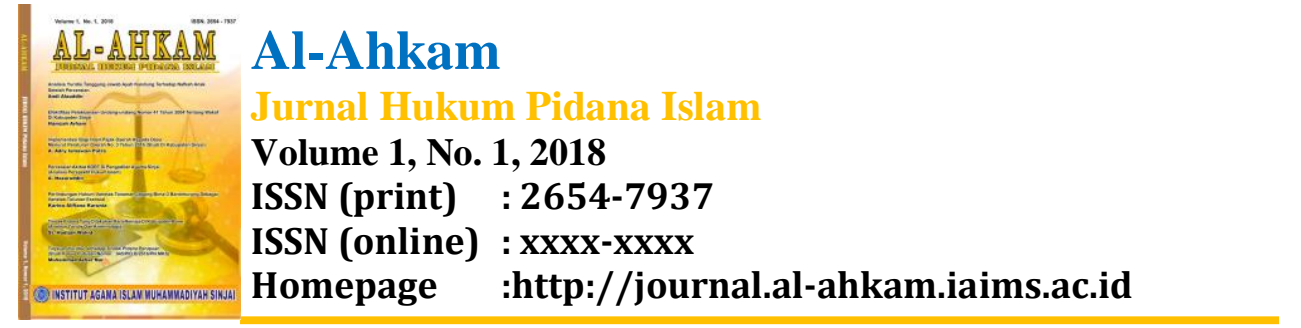

2) Terdakwa telah menikmati hasil kejahatannya.

Keadaan-keadaan yang meringankan:

3) Terdakwa bersikap sopan dan mengakui terus terang perbuatannya;

4) Terdakwa belum pernah dihukum.

Menurut penulis, ada beberapa hal yang sepatutnya dicantumkan dalam amar putusan sebagai alasan pemberat dan peringanan pidana oleh Hakim dalam menjatuhkan putusan kepada terdakwa selain yang dicantumkan dalam putusan, yaitu :

Keadaan-keadaan yang memberatkan:

5) Akibat perbuatan Terdakwa, saksi RIOLA HAYA NUR harus kehilangan suaminya untuk selama-lamanya karena percaya bahwa Terdakwa dapat mengobati mereka dari guna-guna.

Keadaan-keadaan yang meringankan:

6) Terdakwa melakukan tindak pidana ini dikarenakan factor ekonomi dimana Terdakwa harus membiayai pengobatan anaknya yang sedang sakit;

7) Terdakwa merupakan seorang ibu yang mana harus merawat anaknya yang sedang sakit.

Setelah berbagai hal yang telah dijelaskan di atas beserta fakta-fakta hukum yang telah terungkap dipersidangan, dan juga tuntutan pidana yang diajukan oleh Jaksa Penuntut Umum dan ancaman pidana dari tindak pidana yang bersangkutan, maka Majelis Hakim melakukan musyawarah dan berpendapat bahwa pidana yang telah diputuskan tersebut sudah tepat dan sesuai dengan rasa keadilan bagi para tokoh yang bersangkutan.

\section{PENUTUP}

Berdasarkan hasil penelitian dan pembahasan yang telah diuraikan diatas, maka dapat diperoleh kesimpulan sebagai berikut :

1. Penerapan hukum pidana oleh Jaksa Penuntut Umum dan Hakim terhadap pelaku tindak pidana penipuan dalam putusan Nomor: 945/Pid.B/2016/PN.Mks sudah sesuai dengan ketentuan dalam Kitab Hukum Pidana dan Kitab Hukum Acara Pidana, terdakwa didakwakan dengan menggunakan dakwaan alternatif yaitu pertama Pasal 378 KUHP 
Volume 1, No. 1, 2018

ISSN (print) : 2654-7937

ISSN (online) : $x x x x-x x x x$

Homepage :http://journal.al-ahkam.iaims.ac.id

dan/atau kedua Pasal 372 KUHP, dan surat dakwaan yang disusun oleh penuntut umum telah memenuhi syarat formil dan materil. Dalam tuntutannya, Penuntut Umum menuntut terdakwa bersalah melakukan tindak pidana penipuan Pasal 378 KUHP, berdasarkan faktafakta hukum yang terungkap dalam persidangan baik bersumber dari keterangan para saksi maupun keterangan terdakwa, maka penerapan ketentuan pidana pada perkara ini yakni Pasal 378 KUHP telah sesuai dan fakta- fakta di persidangan juga membuktikan bahwa terdakwa telah cakap menurut hukum dan tidak berada di bawah pengampuan, sehingga terdakwa dapat mempertanggung jawabkan hasil dari perbuatan yang telah dilakukannya.

2. Pertimbangan hukum Hakim dalam menjatuhkan sanksi pidana terhadap terdakwa dalam putusan Nomor: 945/Pid.B/2016/PN.Mks terdakwa dipidana dengan pidana penjara 1 (satu) tahun dan 6 (enam) bulan karena terbukti bersalah melakukan tindak pidana penipuan pada Pasal 378 KUHP. Pertimbangan Hakim dalam menerapkan ketentuan pidana terhadap pelaku dalam perkara ini telah sesuai dimana hakim telah mempertimbangkan baik dari fakta-fakta yang terdapat dalam persidangan, keterangan para saksi, keterangan terdakwa, alat bukti

yang ada, keyakinan hakim serta hal-hal yang mendukung dan juga sanksi pidana yang diputuskan masih dalam kategori ringan, serta tidak menimbulkan efek jera kepada terdakwa yang memberikan rasa takut dan trauma bagi terpidana pada khususnya, dan khalayak ramai pada umumnya, sebagaimana fungsi hukuman pidana pada mestinya.

\section{DAFTAR PUSTAKA}

Ali,Achmad.2008.Menguak Tabir Hukum.Bogor: Ghalia Indonesia.

Chazawi,Adami.2010.Pelajaran Hukum Pidana 1. Stelsel Pidana, Tindak Pidana, teori-teori pemidanaan dan Batas Berlakunya Hukum Pidana.Jakarta: PT Raja Grafindo Persada. Ilyas,Amir.2012.Asas-Asas Hukum Pidana.Makassar: Rangkang Education dan PuKAP. Hamzah,Andi.2001.Hukum Acara Pidana Indonesia.Jakarta: Sinar Grafika.

Departemen Pendidikan Nasional.2012., Kamus Besar Bahasa Indonesia, Pusat Bahasa (Edisi Keempat). Jakarta: PT. Gramedia Pustaka Utama.

Effendi,Erdianto.2011.Hukum Pidana Indonesia Suatu Pengantar.Bandung:Refika Aditama. 


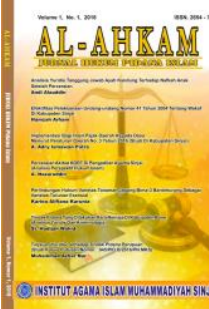
Al-Ahkam
Jurnal Hukum Pidana Islam
Volume 1, No. 1, 2018
ISSN (print) : 2654-7937
ISSN (online) : $x x x x-x x x x$
Homepage :http://journal.al-ahkam.iaims.ac.id

Abdussalam,H.R. 2006.Prospek Hukum Pidana Indonesia Dalam Mewujudkan Rasa Keadilan Masyarakat.Jakarta: Restu Agung.

Mulyadi,Lilik.Hukum Acara Pidana; Normatif, Teoretis, Praktik, dan Permasalahannya.Bandung: PT Alumni.

Hamdan,M. 2000.Tindak Pidana Pencemaran Lingkungan Hidup. Bandung: Mandar Maju.

Marwan, M. dan Jimmy P. 2009.Kamus Hukum, Reality Publisher, Surabaya

Muhammad Ainul Syamsu, 2016, Penjatuhan Pidana dan Dua Prinsip Dasar Hukum Pidana. Jakarta: Kencana.

Moeljatno. 2002. Asas-asas Hukum Pidana. Jakarta: PT Rineka Cipta.

Lamintang, P.A.F. 1997.Dasar-Dasar Hukum Pidana Indonesia.Bandung: PT Citra Aditya Bakti.

Soesilo,R. 1984.Pokok-Pokok Hukum Pidana Peraturan Umum dan DelikDelik Khusus.Bogor: Politeia.

Sugandhi, R. 1980. Kitab Undang-undang Hukum Pidana dan Penjelasannya. Surabaya: Usaha Nasional.

Sudarsono. 2001.Pengantar Ilmu Hukum. Jakarta: PT Rineka Cipta.

Masriani,Yulies Tiena.2004.Pengantar Hukum Indonesia.Jakarta: Sinar Grafika.

UNDANG-UNDANG:

Kitab Undang-Undang Hukum Pidana (KUHP).

Kitab Undang-Undang Hukum Acara Pidana (KUHAP).

Rancangan Undang-Undang Kitab Undang-Undang Hukum Pidana.

SUMBER LAIN:

www.suduthukum.com

www.digilib.uns.ac.id

id.wikipedia.org

www.konsultasihukum 